\title{
Promotion and discipline of employees in private Universities in Uganda
}

\author{
Immaculate Azabo Emurugat*, Sofia Gaite Sol and Yakubu Ibrahim Wunti \\ College of Education, open and distance learning, Kampala International University, Uganda. \\ ${ }^{*}$ Corresponding author. Email: macuemu@gmail.com. Tel: +256 772319549.
}

Copyright @ 2017 Emurugat et al. This article remains permanently open access under the terms of the Creative Commons Attribution License 4.0, which permits unrestricted use, distribution, and reproduction in any medium, provided the original work is properly cited.

\begin{abstract}
The study analyzed the relationship between promotion and discipline of employees in private universities in Uganda. It involved 385 respondents from seven private chartered and accredited universities. Data was collected using a self-administered questionnaire whose validity and reliability was confirmed through Factor Analysis and Cronbach Alpha test. Descriptive analysis involved the use of means (Averages), while Pearson Linear Correlation Coefficient was used to test the hypothesis. The results revealed that promotion was a positive significant determinant of discipline of employees. In conclusion, promotion was an important element in that it influenced the discipline of employees in private universities. It was recommended that managers of Organizations such as private universities should put emphasis on their promotion strategies which will influence the discipline of their employees and thus their rentation.
\end{abstract}

Keywords: Chartered and accredited, hypothesis, reliability, self-administered questionnaire, validity.

\section{INTRODUCTION}

Human resource is the most important factor in determining the purpose of the company or organization. The management of human resources starts with the recruitment process, followed by training and maintenance. A proper management of human resource as to begin early as it will determine the company's or organization's survival. Therefore, leaders need to plan carefully in order to formulate effective strategies and coordinate all components of the company in general and resources in particular (Armstrong, 2000). Employees' performance directly affects the image of an organization in the eyes of society. An effort which could be done to improve employees' performance is to provide motivation like promotion. Superiors hold an important role to motivate employees because when both moral and material encouragement in the form of allowances is given, it is expected to push employees to further improve the results of their work and discipline. The effects of motivation will be present if it is applied in accordance to the employees needs and can be felt not only by employees, but also by the organization. It is likely that lack of promotion may lead to irregular attendance, late marking of students' course work and exams, non-adherence to rules and regulations, dishonesty, non-stability at work place and nonpunctuality. In organizations, discipline is a procedure that corrects or punishes an employee because a rule or procedure has been violated (Dessler, 1996). Therefore, within an organization, discipline must be viewed as a condition whereby employees know what is expected of them in terms of organization's rules standards and policies and what the consequences are of infractions (Rue and Byars, 1996).

This contextual evidence leaves one wondering if the indiscipline in the private universities could be as a result of poor reward management strategies being practiced.

\section{Related Literature}

Promotions are intrinsic rewards which are internal to the employee and are normally derived from involvement in certain activities or tasks. Maicibi and Nkata (2005) stated that, promotions usually bring an increased feeling of self-worth, high salary and higher status in the organization. Maicibi (2013) argued that the maturation of 
employees in the roles to which they are assigned and the kind of individual depends on the opportunities for development of the job through promotions and perception of fair and equal treatment.

Gibson et al., (2009) argued that accurate promotions are based on work place learning, training and career development, performance management, grade and pay structure, mentoring and coaching, Job and work design. However, Ivancevich (2007) noted that for many employees promotions do not happen often and some never experience even one in their career. This implies that managers should look at the type of reward being given because not everyone can be promoted. Promotions involve advancement into positions with greater challenges, more responsibility and more authority than in the previous job (Maicibi and Nkata, 2005). One of the most fundamental concerns of reward management is how high levels of performance can be achieved by motivating people. The development of a performance culture is a typical aim of reward strategy (Ryan, 2013). It is therefore necessary to understand the factors that motivate people and how, in the light of these factors, reward processes and practices can be developed that will enhance motivation, job engagement, commitment and positive discretionary behaviour. A motive is a reason for doing something - for moving in a certain direction. People are motivated when they expect that a course of action is likely to lead to the attainment of a goal - a valued reward that satisfies their particular needs. Well-motivated people are those with clearly defined goals who take action that they expect will achieve those goals (Tibamwenda, 2010).

Employees' satisfaction and motivation may be adversely affected due to job rotation as they find it difficult to develop functional specialties since they spend very little time in one position and thus cannot receive a challenging assignment. Job rotation is used for all types of employees and not just those with managerial potential (Maicibi and Nkata, 2005). For many employees, promotions don't happen often; some never experience even one in their careers. Criteria often used to reach promotion decisions are performance and seniority. Performance, if it can be accurately assessed, is often given significant weight in promotion reward allocation (Gibson et al., 2009).

Discipline like promotion, is an inevitable correlate of organizations and is one of the major functions of performing managers (Itang, 2015; Maicibi, 2007; Pacitti, 2011). Discipline can be defined as a state of self-control and orderly conduct of an individual in accordance with the acceptable standard mode of behaviour. It can also be referred to as the person's ability to control his or her own behaviour so that he/she does what is expected of him or her. It further refers to the practice of training people to obey rules, regulations and orders and punishing them if they do not. When an organization is not satisfied with the behaviour of an employee, it can take disciplinary action against him or her with the view of maintaining standards consistent with an organization's mission and strategic goals (Tibamwenda, 2010). Hersey and Blanchard et al (1993), traced the word "discipline" to have come from the word 'disciple'. Considering a disciple to be a learner, they referred to discipline as a learning process that provides an opportunity for positive growth. However, for organization staff, discipline is a condition where by employees conducts themselves in accordance with the organization rules and standard acceptable behaviour. This definition is the same as the one by Jones et al. (2000), who defined discipline as obedience, synergy, application and other outward mark of respect for superior's authority. It can be further considered as the general conduct or behaviour of people in a particular setting. So, it can be concluded that the discipline in work is an effort of the management of the organization or company to implement or execute the rules or regulations that must be adhered to by all employees without exception. Tibamwenda (2010) defined organization staff discipline as a state of selfcontrol and orderly conduct of an individual in accordance with the acceptable standard mode of behaviour. The aim of this paper is to report on the survey done on the analysis of the relationship between promotion of employees in chartered and accredited private universities in Uganda in relation to their discipline.

\section{METHODOLOGY}

\section{Research design}

The study employed a descriptive cross-sectional survey research design to establish the relationship between promotion and discipline of employees in chartered and accredited private universities. Descriptive survey design enabled the researcher to describe the state of affairs as they are and report the findings (Kothari, 2004). The study adopted concurrent triangulation of both quantitative and qualitative approaches to data collection making it a mixed methods approach. This method allowed rapid collection of data from a large sample within the shortest time possible by use of questionnaires and interview guide. The quantitative research approach was specifically used in order to generate quantifiable data that could explain the relationship between promotion and discipline and the qualitative data was collected so as to capture views and opinions of respondents in regard to promotion and discipline in chartered and accredited private universities.

\section{Research Instrument}

The data collection instruments used were questionnaires and interview guides. Self-constructed questionnaires which comprised of both structured and unstructured 
questions were used in the study. The questionnaire comprised of five sections. Section A was on demographic characteristics of the respondents and had 6 items on gender, age, working experience, academic qualifications, workload and length of stay in a particular university. Section B on promotion which constituted the independent variable (IV) and had 6-items: Work place learning, Training and career development, Performance management, Grade and pay structure, Mentoring and coaching and Job and work design. The third section was on employee discipline and had 12 items which was the dependent variable (DV). The response modes of the questionnaire variables were rated as Strongly Agree (4), Agree (3), Disagree (2) and Strongly Disagree (1).

Interview guides: Interviews were administered to Heads of Departments, University Administrators and Human Resource Personnel. These respondents were interviewed because they had adequate and detailed information on the study variables. A total of fifteen questions were asked for interviewees to give an in-depth opinion about promotion of employees and their discipline in the universities.

\section{Validity of research instrument}

Validity refers to the extent to which the instrument collects data that it is meant to collect. It is the degree to which results obtained from the analysis of the data actually represent the phenomenon under study. In this study, ensuring validity of the data collection instrument involved availing the questionnaires to a panel of experienced researchers in education management of Kampala International University who went through the questionnaire in relation to the set objectives and made sure that it contains all the information that can enable answer the objectives. The results from the piloting study together with the comments from the experts were incorporated in the final instrument revisions to improve its validity. The validity of the instruments was constructed by using educational expert judgment method suggested by Gay (1996) and refined based on expert advice.

The following formula was used to test the content validity index.

$\mathrm{CVI}=\frac{\text { No. of items considered relevenat by Judges }}{\text { Total number of Items Judged }} x 100$

Where CVI is the Content Validity Index

After collection of quantitative data, the validity of the multi-item variables was also tested using confirmatory factor analysis. In considering construct validity, only items whose first component/factor had an eigen value that exceeded 1.00 were rotated for interpretation. Items with values of 0.50 and above were adopted while those with values less than 0.50 were considered weak, hence dropped.

\section{Reliability}

Reliability of the study instruments were ascertained by pre-testing the questionnaires and interview guide in the field. This was piloted using thirty employees from Islamic University in Uganda (IUIU) who were not part of the respondents. The Cronbach alpha for the two constructs were; promotion $(\alpha=.684)$ and Discipline $(\alpha=.804)$. The overall Cronbach alpha was 0.761 for employee questionnaire which is above the benchmark 0.7 (Amin, 2005) and therefore both constructs were considered reliable and thus the instruments were adopted for the study.

\section{Target population}

The target population was 7,185 employees by the year 2016 from the Private Universities in Uganda. The population included employees of private chartered and accredited Universities such as lecturers (7164), University Administrators (7), Heads of Departments (7) and the Human Resource Personnel (7). The Seven Private Universities were purposively chosen on the basis that in addition to being chartered, they are accredited implying that they have met the required standards of operating as universities.

\section{Sample size}

The sample size for the study was calculated based on Krejcie and Morgan (1970) formula, given as;

$$
\mathrm{n}=\frac{X^{2} * N * P(1-P)}{\left(M E^{2} *(N-1)\right)+\left(X^{2} * P *(1-P)\right)}
$$

Where, $\mathrm{n}=$ Sample size, $\mathrm{X}^{2}=$ Chi Square for the specified confidence level at 1 degree of freedom = (3.841) from tables, $\mathrm{N}=$ Population size, $\mathrm{P}=$ Population proportion (0.50 in the table), ME=Desired margin of error (expressed as a proportion $=0.05$ ).

$$
\begin{aligned}
& \text { Sample size } \\
& =\frac{3.841 \times 7184 \times 0.5(1-0.5)}{0.05 \times 0.05(7184-1)+3.841 \times 0.5(1-0.5)} \\
& \text { Sample size }=\frac{6879.231}{918.86775} \\
& \text { Sample size }=365 \text { lecturers }
\end{aligned}
$$

Furthermore, 7 University Administrators, 7 Human Resource Personnel and 7 Head of Departments were included in the study giving a sample size of 386

\section{Sample selection and procedure}

A copy of the introduction letter was obtained from College of Education, Distance and e-Learning (COEDL) 
for the researcher to seek approval to conduct the study in the various universities. Once approved by the University Authorities the researcher requested for a list of employees from the Human Resource Department of each University under study and selected respondents. The researcher guided the research assistants with reference to sampling procedure and data collection and also reproduced questionnaires for distribution. The questionnaires were administered to University Employees with the help of research assistants (Lecturers), while the researcher administered the interview schedules to human resource development officers in the seven Universities in order to get in-depth data.

Lecturers, University Administrators, Head of Departments and Human Resource Personnel in the Private Universities provided the statistical population.

Purposive sampling was used to select the University Administrators, Human Resource Personnel and Heads of Departments in this study as this category has in depth information about promotion and the discipline of employees in the Private Universities.

Stratified sampling was used to select large groupings from the above mentioned category and then sampling units from within the clusters followed the application of random sampling.

For universities involved in the study, A register of chartered and accredited universities obtained from the National Council for Higher Education (NCHE) was used and from this register chartered and accredited private universities were purposively drawn to create sampling units using multi-stage.The Private Universities from which respondents were drawn were Bugema University, Kampala International University (KIU), Kampala University (KU), Ndejje University, Nkumba University, Uganda Christian University and Uganda Martyrs University

\section{Ethical Consideration}

This work was approved by the ethical steering committee of Kampala International University. The respondents' participation was voluntary and free. During the research, there was no promise of benefits for participation and the respondents were required to sign the informed consent letter. The respondents were further assured of privacy and confidentiality of the information obtained from them. The researcher has acknowledged the authors mentioned in the study by documenting in references and citing authors. The presentations of the findings have also been generalized. Permission was sought and granted by the ethical steering committees of the various universities which were included in the study.

\section{Data processing and analysis}

\section{Quantitative data}

Data from the proposed research was coded, processed and analyzed using computer based statistical package for social sciences (SPSS). Descriptive statistics in form of frequencies, percentages and mean were used to make comparisons of the responses. The hypothesis that there is a relationship between promotion and discipline of employees in private Universities in Uganda was tested using Pearson Product Moment Correlation Coefficient. This is because the hypothesis is concerned with relationships, and it is Pearson Correlation Coefficient that is appropriate for testing such relationships. In addition, multiple regression analysis was used to test the relationships. Using regression, the DV which was Employee discipline was regressed on the independent variables (IV) promotion.

\section{Qualitative data}

Data that was collected during the interviews was also presented and discussed to supplement the quantitative data to bring out the meaning clearly for easy understanding by the readers. The qualitative data collected using interviews and the open-ended questionnaire in the semi-structured questionnaire was basically on the relevant aspect of the research and was analysed using content analysis.

\section{RESULTS AND DISCUSSIONS}

\section{Demographic characteristics of the respondents}

Out of the three hundred and nine (309) respondents, one hundred and seventy two (172) or $55.7 \%$ were male while one hundred thirty seven (137) or $44.3 \%$ were females (Figure 1). The study findings showed that a majority $(55.7 \%)$ of the respondents were male. This implies that there were more male lecturers working in private universities in Uganda as compared to their female counterparts. This contradicts the findings of Nguyen et al. (2003) which revealed that more women were working in private universities than men. This has been attributed to a lower expectation on the job due to the conventional poor position of women in the labor market (Blanchflower and Oswald, 2000). However, Ibrahim et al., (2011) argued that gender has insignificant influence on job satisfaction and promotion. From the study it can be shown that males could be more satisfied in their work as compared to the females especially in the teaching profession.

\section{Highest academic qualification of the respondents}

From the results obtained, thirty six (36) or $11.7 \%$ out of three hundred and nine respondents (309) have $\mathrm{PhD}$ degrees, one hundred and ninety four (194) or (62.8\%) have master's degree, seventy six (76) respondents or 


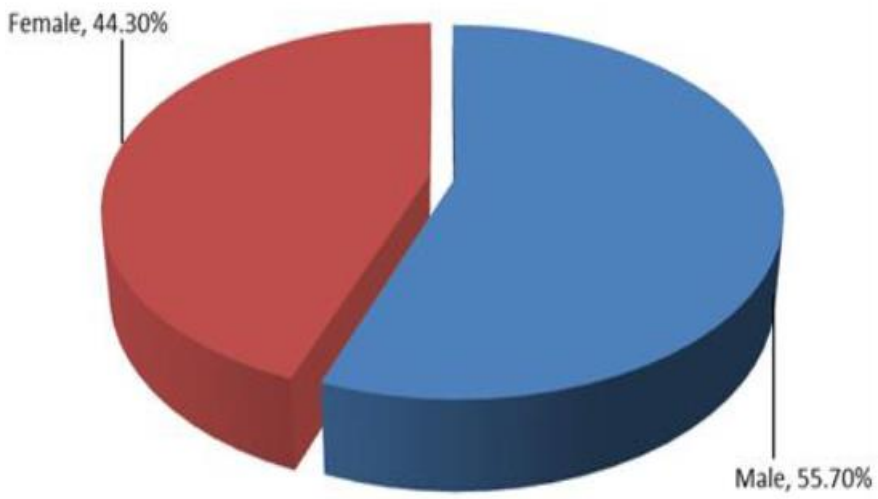

Figure 1. Gender of the Respondents.

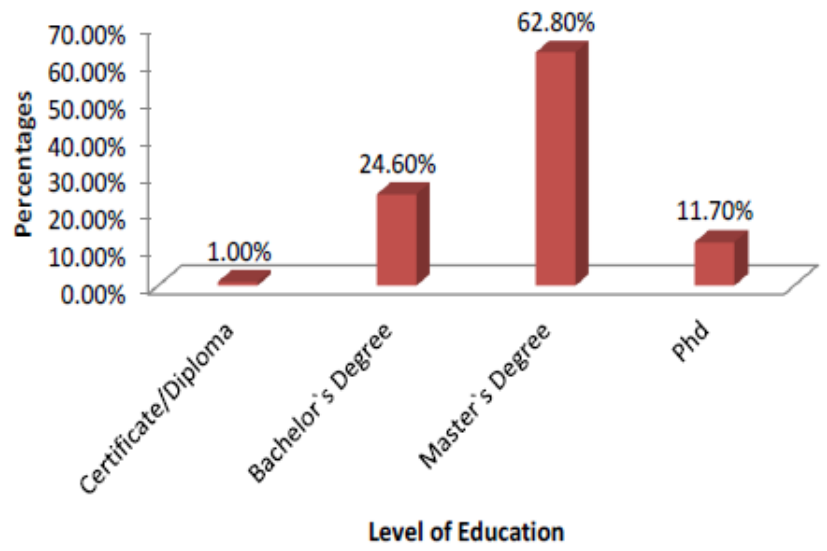

Figure 2. Highest academic qualification of the Respondents.

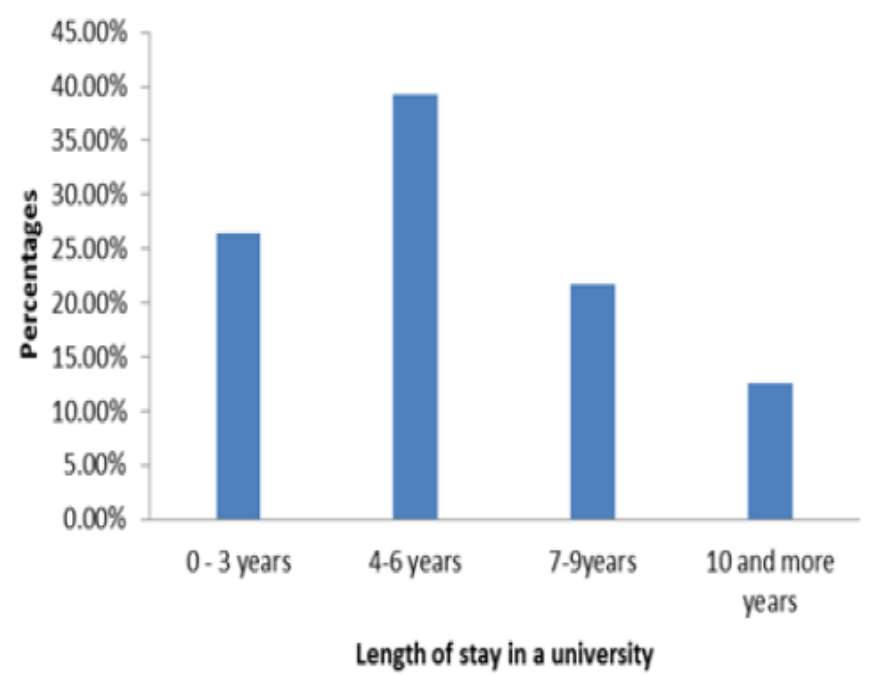

Figure 3. Length of stay in the University.
(24.6\%) have Bachelor's degree and three (3) or (1.0\%) respondents have certificates/diplomas (Figure 2). From the responses, it can be deduced that the majority $(62.8 \%)$ of the respondents were master degree holders. This shows that majority of the staff working in private universities in Uganda are master degree holders. According to Saif-Ud-Din et al. (2012), education level of employees is critical in defining job satisfaction in any organization. In this study, there were a low number of $\mathrm{PhD}$ holders in private universities showing that maybe some employees migrate to public universities or other organizations where they are rewarded well and are more satisfied with their work.

\section{Length of stay in the University}

Figure 3 showed that one hundred and twenty one (121) or $(39.2 \%)$ of the respondents out of the three hundred and nine have stayed in the current University where they are employed for 4 to 6 years, eighty two (82) or $26.5 \%$ have stayed in the current university where they teach for less than three years, sixty seven (67) or $21.7 \%$ of the respondents have stayed between 7 to 9 years in the present university they are teaching and thirty nine (39) or $12.6 \%$ of the employees have stayed for more than ten (10) years in the private university where they are currently teaching. This shows that most of the private university employees had stayed in one university for a period of 4 to 6 years. This shows that most of the private university employees in Uganda leave their employment earlier. An indication that they were not satisfied with their work as stated by McEwen (2011) who noted that work engagement comes from the perceptions and evaluations of employees toward their working experience and benefits from their employers.

\section{Working status of the respondents}

Figure 4 shows that out of the three hundred nine (309) respondents, one hundred and forty seven (147) or $47.6 \%$ are permanent employees, ninety one (91) or $29.4 \%$ are part time employees which mean that they are teaching in other universities and seventy one (71) or $23.0 \%$ are working as contractual or casual employees of the university. This shows that majority of the employees in the private universities are employed permanently, indicating that most of the private universities in Uganda recruit their employees as permanent and full time staff.

\section{Discipline of Employees}

The dependent variable was divided into aspects namely; attend to their duties regularly at the university, mark student's course works in time, follow rules and regulations, work in other universities apart from the one I am teaching, not punctual and punished after some time, 


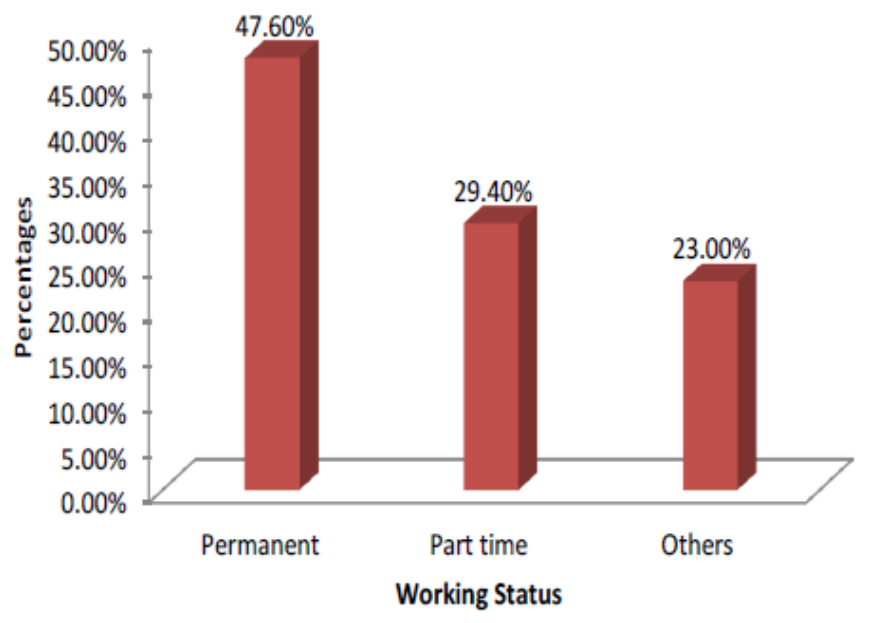

Figure 4. Working Status of the Respondents $(n=309)$.

accomplish all tasks and assignments in time, accountable for their actions, responsibility of taking care of goods and property, I am satisfied with my job and thus very honest in carrying out my duties, salary I earn is enough for me to remain working and my university has an employee handbook about the rules and regulations of my institution. The items were scaled using the four point Likert scale ranging from a minimum of 1 for the worst case scenario (Strongly disagree) to a maximum of 4 , which is the best case scenario (strongly agree). Table 1 illustrates all the elements of discipline as listed above. From the Table 1, it is observed that most of respondents agreed with the statements in the list since their means were above 3 on the Likert scale apart from two issues on I am satisfied with my job and thus very honest in carrying out my duties and salary I earn is enough for me to remain working which had a mean less than 3 . However, an overall mean of about 3 , which on the scale used corresponded to agree and hence a good overall rating of discipline in private universities.

Table 1 shows statements on employee discipline. In item one with the statement that "employees attend to their duties regularly at the university", out of three hundred and nine (309) respondents, one hundred seventy six (176) or $57.0 \%$ respondents agreed, one hundred eight (108) or $35.0 \%$ respondents strongly agreed and twenty two (22) or $7.1 \%$ respondents disagreed while three (3) or $1.0 \%$ respondents strongly disagreed. The study found a mean of $3.42 \pm 0.876$ which reflects a positive response. It shows that majority $(92.0 \%)$ of the private universities staff in Uganda reported that employees in private universities attended to their duties on regular basis. This implies that majority of the private university employees in Uganda are committed when it comes to attendance of duty thus implying that they are disciplined.

Similarly, in item 2 with the statement that 'employees mark student's course works in time in their universities', out of three hundred and nine (309) respondents, one hundred eighty two (182) or $58.9 \%$ respondents agreed, eighty seven (87) or $28.2 \%$ respondents strongly agreed and thirty seven (37) or (12.0\%) respondents disagreed with the statement while three (3) or $1.0 \%$ respondents strongly disagreed with the statement. From the responses, a mean score of $3.46 \pm 0.912$ was obtained which is interpreted as very good. It shows that majority $(87.1 \%)$ of the respondents noted that students' work were marked in time by lecturers and this was a sign of employee discipline in the organization. Timely working on assignments given is an indication that the employees are committed and thus disciplined on their work.

Furthermore, on item 3 with the statement that 'employee's always follow rules and regulations of the university', out of three hundred and nine (309) respondents one hundred and eighty nine (189) or $61.2 \%$ respondents agreed , sixty nine (69) or $22.3 \%$ respondents strongly agreed and forty six (46) or (14.9\%) respondents disagreed while five (5) or $1.6 \%$ respondents strongly disagreed. From the responses, a mean of $3.51 \pm 0.867$ was obtained which meant very good. It emerged from the responses that majority $(83.5 \%)$ of the employees in private universities adhered to set rules and regulations within the university. This shows that employees are obedient and adhere to rules and regulations which govern their work and this is a sign of employee work discipline in any organization.

In addition, on item 4 with the statement that 'employees work in other universities apart from the one they were teaching in', out of three hundred and nine (309) respondents one hundred thirty seven (137) or $44.3 \%$ respondents agreed, eighty five (85) or $27.5 \%$ respondents disagreed and sixty three (63) or $20.4 \%$ respondents strongly agreed while twenty four (24) or $7.8 \%$ respondents strongly disagreed. From the responses, a mean score of $3.28 \pm 0.991$ was obtained which implies very good. It shows that majority (64.7\%) of the employees in private universities reported that their colleagues are working as part-timers in other universities. This shows that the remuneration packages being offered by private universities are not adequate to cater for the needs of its employees and therefore they (employees) work as part-timers in other universities with an aim of increasing their income. This implies that since most employees in private universities have part time jobs in other universities there could be a conflict of interest and the employee cannot be effective in his or her work hence it causes problems especially in the university where he or he/she is redundant and ineffective.

Furthermore on item 5 with the statement that 'employees who are not punctual were punished after some time in their universities', out of three hundred and nine (309) respondents, one hundred and thirty three (133) or $43.0 \%$ respondents agreed, one hundred eighteen (118) or $38.2 \%$ respondents strongly agreed, thirty eight (38) or $12.3 \%$ respondents strongly disagreed 
Table 1. Frequency, Percentages and Means of Employee Discipline $(n=309)$.

\begin{tabular}{|c|c|c|c|c|c|c|c|c|c|c|c|}
\hline \multirow{2}{*}{ Statement } & \multicolumn{2}{|c|}{ SD } & \multicolumn{2}{|c|}{ D } & \multicolumn{2}{|c|}{ A } & \multicolumn{2}{|c|}{ SA } & \multirow{2}{*}{ Mean } & \multirow{2}{*}{ Std Dev. } & \multirow{2}{*}{ Remarks } \\
\hline & $\mathbf{F}$ & $\%$ & $\mathbf{F}$ & $\%$ & $\mathbf{F}$ & $\%$ & $\mathbf{F}$ & $\%$ & & & \\
\hline $\begin{array}{l}\text { Employees attend to their duties regularly at the } \\
\text { university }\end{array}$ & 3 & 1.0 & 22 & 7.1 & 176 & 57.0 & 108 & 35.0 & 3.42 & .876 & Very Good \\
\hline $\begin{array}{l}\text { Employees mark student's course works in time in my } \\
\text { university }\end{array}$ & 3 & 1.0 & 37 & 12.0 & 182 & 58.9 & 87 & 28.2 & 3.46 & .912 & Very Good \\
\hline $\begin{array}{l}\text { Employee's always follow rules and regulations of the } \\
\text { university }\end{array}$ & 5 & 1.6 & 46 & 14.9 & 189 & 61.2 & 69 & 22.3 & 3.51 & .867 & Very Good \\
\hline $\begin{array}{l}\text { Employees work in other universities apart from the one } \\
\text { I am teaching in. }\end{array}$ & 24 & 7.8 & 85 & 27.5 & 137 & 44.3 & 63 & 20.4 & 3.28 & .991 & Very Good \\
\hline $\begin{array}{l}\text { Employees who are not punctual are punished after } \\
\text { some time in my university. }\end{array}$ & 38 & 12.3 & 20 & 6.5 & 133 & 43.0 & 118 & 38.2 & 3.33 & 1.004 & Very Good \\
\hline $\begin{array}{l}\text { Employees accomplish all tasks and assignments in } \\
\text { time at the university. }\end{array}$ & 20 & 6.5 & 87 & 28.2 & 160 & 51.8 & 42 & 13.6 & 3.49 & .882 & Very Good \\
\hline $\begin{array}{l}\text { Employees are accountable for their actions in the } \\
\text { university. }\end{array}$ & 14 & 4.5 & 37 & 12.0 & 195 & 63.1 & 63 & 20.4 & 3.53 & .789 & Very Good \\
\hline $\begin{array}{l}\text { Employees have the responsibility of taking care of } \\
\text { goods and property of the university. }\end{array}$ & 11 & 3.6 & 48 & 15.5 & 165 & 53.4 & 85 & 27.5 & 3.44 & .942 & Very Good \\
\hline $\begin{array}{l}\text { I am satisfied with my job and thus very honest in } \\
\text { carrying out my duties. }\end{array}$ & 79 & 25.6 & 142 & 46.0 & 65 & 21.0 & 23 & 7.4 & 1.45 & 1.245 & Poor \\
\hline $\begin{array}{l}\text { The salary I earn is enough for me to remain working at } \\
\text { my university. }\end{array}$ & 74 & 23.9 & 115 & 37.2 & 91 & 29.4 & 29 & 9.4 & 1.32 & 1.082 & Poor \\
\hline $\begin{array}{l}\text { My university has an Employee Handbook about the } \\
\text { rules and regulations of my institution }\end{array}$ & 42 & 13.6 & 54 & 17.5 & 109 & 35.3 & 104 & 33.7 & 3.31 & .987 & Very Good \\
\hline Average Mean & & & & & & & & & 3.05 & .962 & \\
\hline
\end{tabular}

Source: Field Data, 2016.

while twenty (20) or $6.5 \%$ respondents disagreed with the statement. A mean of $3.33 \pm 1.004$ was obtained meaning very good. This shows that majority $(81.2 \%)$ of the private universities employees believed that employees who reported to work late were punished. The punishment that is given to university employees includes withholding of salaries, reduction of salaries as per the number of hours they attend to their work and sometimes termination of their services which in the long run leads to indiscipline. The punishment can also be effective so that the employee will do his or her work effectively so as not to jeopardize the students.
Moreover, on item 6 with the statement that 'employees were accountable for their actions in the university', out of three hundred and nine (309) respondents, one hundred ninety five (195) or $63.1 \%$ respondents agreed, sixty three $(63)$ or $20.4 \%$ respondents strongly agreed and thirty seven (37) or $12.0 \%$ respondents disagreed while fourteen (14) or $4.5 \%$ respondents strongly disagreed. A mean score of $3.49 \pm 0.882$ was obtained meaning very good. This shows that majority $(83.5 \%)$ of the university employees believed that they were accountable for their actions while in the university and accountability is very important in any learning institution especially in private universities to avoid pointing fingers to anybody. Accountability is a sign of maturity, responsibility and professionalism.

In addition, on item 7 with the statement that 'employees had the responsibility of taking care of goods and property of the university', out of three hundred and nine (309) respondents, one hundred sixty five (165) or $53.4 \%$ respondents agreed 85 or $27.5 \%$ respondents strongly agreed and forty eight (48) or $15.5 \%$ respondents disagreed while eleven (11) or $3.6 \%$ respondents strongly disagreed. A mean of $3.44 \pm 0.942$ was obtained which is interpreted as very good. This shows that majority $(80.9 \%)$ of the university 
employees believed that they had the responsibility of taking care of the university properties. The act of being responsible by taking care of university property is a sign of commitment and concern for the university.

However, on item 8 with the statement that 'employees were satisfied with their jobs and thus very honest in carrying out their duties', out of three hundred and nine (309) respondents 142 or (46.0\%) respondents disagreed with the statement, 79 or $(25.6 \%)$ respondents strongly disagreed with the statement and 65 or $(21.0 \%)$ respondents agreed with the statement while 23 or $(7.4 \%)$ respondents strongly agreed with the statement. From the responses, a mean of $1.45 \pm 1.245$ was obtained which is interpreted as poor. From this statement majority $(71.6 \%)$ of the university employees in private universities were not satisfied with their jobs and were not honest in carrying out their duties. This shows that employees in private universities are not committed to their work and thus had low morale to perform their duties. They only performed their duties to earn salary and to avoid being terminated from work. Honesty is one of the virtues of a good employee. If most employees are not honest then a lot of problems will crop up like changing of students marks, allowing bribery from students, allowing examination malpractice among others which creates problems for the university. The university must put a mechanism to prevent such behaviour from employees especially lecturers.

Similarly, on item 9 with the statement that 'the salary the employees earned was enough for them to remain working at their universities', out of three hundred and nine (309) respondents 115 or (37.2\%) respondents disagreed with the statement, 91 or $(29.4 \%)$ respondents agreed with the statement and 74 or $(23.9 \%)$ respondents strongly disagreed with the statement while 29 or $(9.4 \%)$ respondents strongly agreed with the statement. From the responses, a mean score of 1.32 \pm 1.082 was obtained which means poor. This shows that majority $(61.1 \%)$ of the employees in private universities in Uganda were not satisfied with their salary and could leave for better pay jobs in other organizations. This implies that private universities pay inadequate salaries for its employees and therefore they are not satisfied with their work.

Since most of the private universities in Uganda do not give better salary to their employees some employees end up doing part time jobs in other universities and others end up leaving the university for better paying organizations. The university must find a way to improve the salary of the employees so that they can do their jobs well rather than teaching in different universities.

In addition to that, Item 10 with the statement that 'universities had an Employee Handbook about the rules and regulations of their institutions', out of three hundred and nine (309) respondents 109 or (35.3\%) employees agreed with the statement, 104 or $(33.7 \%)$ respondents strongly agreed with the statement, 54 or $(17.5 \%)$ respondents disagreed with the statement while 42 or $(13.6 \%)$ respondents strongly disagreed with the statement. From the responses, a mean score of $3.31 \pm$ 0.987 was obtained which is very good. This shows that the majority $(89.0 \%)$ of the employees in private universities were aware of the rules and regulations governing their institutions although sometimes some employees do not follow rules and regulations of the university especially if the university is not strict on the implementation of its policies.

Table 2 shows that item one which states that 'employees receive training and career development in their universities', out of three hundred and nine (309) respondents 160 or $51.8 \%$ respondents agreed, sixty two (62) or $20.1 \%$ respondents disagreed, fifty six (56) or $18.1 \%$ respondents strongly agreed while thirty one (31) or $10.0 \%$ respondents strongly disagreed. The study found a mean score of $2.14 \pm 1.007$ which means fair. This shows that majority $(69.9 \%)$ of the private universities employees in Uganda received training and career development from their employers. This implies that employees in private universities are given scholarships to study and obtain skills which are necessary for their careers. In turn, training will boost the morale of the employees making them satisfied and committed to the work and thus being disciplined in the university.

Similarly, in item 2 which states that "employees are offered a flexible job and work design", out of the three hundred and nine respondents (309) respondents, one hundred and forty nine agreed (149) or $48.2 \%$ agreed, one hundred three 103 or $33.3 \%$ of the respondents disagreed and thirty three (33) or $10.7 \%$ of the respondents strongly agreed and twenty four (24) or $7.8 \%$ of the respondents strongly disagreed. From the responses, a mean score of $1.62 \pm 0.976$ was obtained, which is interpreted as fair. It can therefore be argued that majority $(58.9 \%)$ of the university staff members believed that they were given flexible job and work design. Flexibility in jobs allows one to have better worklife balance and therefore reduce on job related stress which can make them to perform their job well.

Furthermore in item 3 which states that "employees are provided with opportunities for work place learning", out of three hundred and nine (309) respondents, one hundred fifty seven (157) or $50.8 \%$ respondents agreed, eighty four (84) or $27.2 \%$ respondents disagreed and thirty eight (38) or $12.3 \%$ respondents strongly disagreed while thirty (30) or $9.7 \%$ ) respondents strongly agreed. From the responses, a mean score of $2.07 \pm 1.109$ was obtained which means fair. It can be argued that majority $(60.5 \%)$ of the employees in private universities in Uganda reported that they were provided with opportunities for work place learning which can inspire employees to work better.

In addition, in item 4 which states that "the university employees are promoted immediately they get better 
Table 2. Employees' Responses on their Promotion in Private Universities $(n=309)$.

\begin{tabular}{|c|c|c|c|c|c|c|c|c|c|c|c|}
\hline \multirow{2}{*}{ Statement } & \multicolumn{2}{|c|}{ SD } & \multicolumn{2}{|c|}{$\mathbf{D}$} & \multicolumn{2}{|c|}{ A } & \multicolumn{2}{|c|}{ SA } & \multirow{2}{*}{ Mean } & \multirow{2}{*}{ Std Dev. } & \multirow{2}{*}{ Interpretation } \\
\hline & $\mathbf{F}$ & $\%$ & $\mathbf{F}$ & $\%$ & $\mathbf{F}$ & $\%$ & $\mathbf{F}$ & $\%$ & & & \\
\hline Employees receive training and career development in my university & 31 & 10.0 & 62 & 20.1 & 160 & 51.8 & 56 & 18.1 & 2.14 & 1.007 & Fair \\
\hline Employees are offered a flexible job and work design & 24 & 7.8 & 103 & 33.3 & 149 & 48.2 & 33 & 10.7 & 1.62 & .976 & Poor \\
\hline Employees are provided with opportunities for work place learning & 38 & 12.3 & 84 & 27.2 & 157 & 50.8 & 30 & 9.7 & 2.07 & 1.109 & Fair \\
\hline $\begin{array}{l}\text { The university employees are promoted immediately they get better } \\
\text { qualifications in my university }\end{array}$ & 24 & 7.8 & 102 & 33.0 & 107 & 34.6 & 76 & 24.6 & 2.21 & 1.203 & Fair \\
\hline Average Mean & & & & & & & & & 2.01 & 1.074 & Fair \\
\hline
\end{tabular}

Source: Field Data, 2016.

Table 3. Relationship between Promotion and Discipline of Employees.

\begin{tabular}{lccc}
\hline Variables correlated & Computed r- value & P- value Sig. (2tailed) & Interpretation of correlation \\
\hline Promotion and Discipline & 0.679 & 0.010 & Significant relationship \\
\hline${ }^{* *}$ Correlation is significant at the 0.01 level $(2$-tailed). & &
\end{tabular}

qualifications", out of three hundred and nine (309) respondents one hundred seven (107) or $34.6 \%$ respondents agreed, one hundred two (102) or $33.0 \%$ respondents disagreed and seventy six (76) or $24.6 \%$ respondents strongly agreed while twenty four (24) or $7.8 \%$ respondents strongly disagreed. A mean of 2.21 \pm 1.203 was obtained which means fair. This shows that majority $(59.2 \%)$ of the employees agree that private universities usually promoted employees immediately they got better qualifications. Promoting employees immediately after they get their qualifications will make employees committed to their work and thus inspire them to strive better.

An average mean score of $2.01 \pm 1.074$ was obtained which means fair from all the statements on promotion and employee discipline showing that promotion policies in private universities in Uganda are fairly done as per university rules and regulations.
Table 3 shows that there was a significant and positive correlation between promotion and discipline of employees $(r=0.679 ; p=0.010)$ This implies that promotion influences positively employee discipline in private universities. Therefore, the hypothesis which stated that there is a relationship between promotion and discipline of employees in private Universities in Uganda was accepted because of the significance value of 0.010 . This means that private universities should strengthen their promotion policies and encourage employees to update their documents and apply for promotion when deemed necessary. The university promotion committee must also be put in place and should carry its duties of promoting employees who qualify.

The results show that the independent variable 'promotion' has influence upon discipline (dependent Variable) of employees in private universities. Therefore, the hypothesis that there is a relationship between promotion and discipline of employees in private Universities in Uganda is supported. This implies that the independent variable promotion explains the variance in dependent variable, discipline. Therefore the results uncover the information that promotion has a high explanatory power in explaining the discipline of employees in private universities.

This research examined the relationship between promotion and discipline of employees in private universities in Uganda. The findings reveal that promotion has significant impact on discipline of employees in private universities. Other factors except promotion can also be useful in the research.

The university administrators and human resource were interviewed on employee promotion and discipline. According to the majority of the university administrators, promotion of staff is done according to university policies and regulations and it mainly depends on the qualification and performance of the employees. 
One Head of department explained that, "In any academic institution promotion should be based on one's qualification. This promotion should be effected immediately to enable other upcoming academicians to strive to acquire better qualifications in their profession".

One human resource personnel explained that, "when you do not promote your employees they become demotivated and thus end up being undisciplined'.

Majority of the university administrators and human resource agreed that promotion of employees could enable them to become more disciplined because they would feel valued in the university. This made the researcher to conclude that when employees are promoted at work they become more disciplined because of the new roles they assume.

\section{Conclusions}

The study concluded that promotion had a positive significant effect on the discipline of employees in private universities in Uganda. When employees are satisfied with their job as a result of promotion, this implies that their efforts are being recognized and thus less likely to run off from job and have low absenteeism rate and hence become more productive than before and even their behaviour changes in anticipation for further promotion.

The findings of the current study were cross-referenced with those of scholars in other organizational environments and displayed similar relationship. For example Decerizo and Robins (2002), observed that in the organization, the main form of reward for merit has been promotion to the next grade. They emphasized that the prospect of promotion is the main incentive for employees to perform well in their current grades. This is supported by Newman (2012) who observes that employees are more likely to behave honesty and get committed on their jobs if they believe their organization is committed to their career advancements.

\section{Recommendations}

Promotion has been known to have a positive effect on employee discipline. However different private universities motivate differently. It should also be noted that motivation is personal and what motivates one employee could be different from what motivates the next. Therefore, the private universities should get to know their employees well so that they can employ the right motivational strategy.

Further research can be conducted by including more private universities and broadening sample size. In this research only one influencing factor promotion was used, in future more influencing factors of job satisfaction can be studied like job security, fringe benefits, supervision.

\section{CONFLICT OF INTEREST}

The authors declare that they have no conflict of interest.

\section{REFERENCES}

Amin, M. E. (2005). Social science Research: Conception, Methodology and Analysis. Kampala,Uganda: Makerere University Syversion, C. (2011). What determines productivity? Journal of Economic literature, 49(2), 326-365.

Blanchflower, D., \& Oswald, A. (2000). The rising well-being of the young, in Youth Employment and Joblessness in Advanced Countries, edited by Blanchflower, D., \& Freeman R, Chicago: The University of Chicago Press. Pp. 289-328.

Decerizo, H. F., \& Robbins, J. (2002). Early Professional Development. London Rontledge Palmen.

Dessler, G. (1996). Human Resource Management, 7th ed, England wood Cliffs, NJ: Prentice Hall, p. 174.

Gay, L. R. (1996). Educational research: Competencies for analysis and application (5th ed.). New York: Macmillan. p. 217

Gibson, J. L., Ivancevich, J. M., Donnelly, J. H., \& Konapaske, R. (2009). Organisations Behavior, Structure, Processes,McGraw -Hill Irwin, New York. Pp. 89-123.

Hersey, P., \& Blanchard, K. H. (1993). Management of Organizational Behaviour ( $6^{\text {th }}$ ed.) Englewood Cliff, N. J. Prentice Hall. p. 269.

Ibrahim. M., Abdulazim, G., Elkhouly, S., \& Mohsen, G. (2011). Impact of emotional intelligence and gender on job satisfaction among Egyptian Government Sector employees. Current Research Journal of Social Sciences, 3(1), 22-27.

Itang, I. (2015). Work Discipline and Work Competence with Quality of Service in the Office of Religious Affairs (KUA) District of Mount Kencana Lebak Regency of Banten. Journal of Management and Sustainability, 5(3), 132.

Ivancevich, J. M. (2007).Human Resource Management, 10th ed. Boston: McGraw-Hill Irwin. p. 422.

Jones, G. R., George, J. M., \& Hill, C. W. L. (2000). Contemporary Management, $\left(2^{\text {nd }}\right)$ Irwin: McGraw Hill Ltd. Pp. 613-615.

Kothari, C. R. (2004). Research Methodology: Methods and Techniques. Second edition, age International publishers. Pp. 2-7.

Krejcie, R. V., \& Morgan, D. W. (1970). Determining sample size for research activities. Educational and Psychological measurement, 30, 607-610.

Maicibi N. A., \& Nkata, J. L. (2005). Introduction to Human Resource Management. Masah Publishers Kampala Uganda, Pp. 185-188.

Maicibi, A. (2007). Human Resource Management Success. Makerere University Printery, Kampala, Uganda, Pp. 208223.

Maicibi, N. A. (2013). The Managers Companion and Manual of Organizational Behaviour. Fountain publisher, Kampala, Uganda.

McEwen, D. (2011). Employee engagement: A Systemic approach to high employee engagement. Available at: http://www.cgnglobal.com /sites/default/files/ Employee_ Engagement_CGN\%20Global.pdf.

Newman, S. (2012). Organizational rewards and employee commitment: a Chinese study. Journal of Managerial Psychology, 27(1), 71-89. 
Nguyen, A., Taylor, J., \& Bradley, S. (2003). Relative pay and job satisfaction: some new evidence. Munich Personal RePec Archive. Development and Policies Research Centre. Pp. 124

Pacitti. (2011). Efficiency Wages, Unemployment, And Labor Discipline. Journal of Business and Economics Research, 9(3), 1-10.

Saif-Ud-Din, K., Nawaz, A., \& Jan, F. A. (2012). Impact of Demographic Diversities on the Job Satisfaction and its Consequences: Case of Academicians in Higher Learning Institutions of Pakistan. Global Journal of Management and Business Research, 12(19), 35-43.
Rue, L. W., \& Byars, L.L., (1996). Supervision: key link to productivity (5 $5^{\text {th }}$ ed.). Chicago: Irwin. Pp. 276-278.

Ryan, N. (2013). Reward schemes for employees and Management. Unpublished Paper.

Sutrisno, E. (2011). Human Resource Management. Jakarta: KencanaPrenada Media Group.

Tibamwenda, J. (2010). Modern Management Theories and Practices- A productivity and profitability Approach. Macmillan Uganda Limited, Uganda, Pp. 442-452. 